\title{
Using games during online English classes in Zoom (based on author's personal experience)
}

\author{
Shokarova N.* \\ Kharkiv Specialised School № 11, Kharkiv, Ukraine
}

Received: $10.06 .2020 \quad$ Accepted: 24.06 .2020

\begin{abstract}
The article is dedicated to adapting traditional games in English lessons to using them during classes on Zoom video conferencing platform, based on the author's own experience. The development of technology in the modern world allows us to take our classes beyond our classrooms and to conduct them where we consider it convenient. This makes it possible not to stop the learning process even in the context of a pandemic or under some other conditions that prevent our students from attending traditional classes. Using Zoom to learn and teach English also provides new opportunities to turn the ordinary tasks we are used to during our classes into unusual ones. Games occupy an important place in the process of mental development of pupils at different levels of language acquisition. They entertain, help to revise and recycle vocabulary, improve grammar skills, tune in for a lesson, etc. At the same time, distance learning in the spring of 2020 in Ukraine showed the need to use technologies and the Internet during the educational process, which in its turn led to the need to find optimal conditions for studying in order not to interrupt it in the circumstances of a world pandemic. Excessive use of technology has negative effects on pupils. In such conditions, games become not only a tool for learning, but also a means of achieving maximum result with minimal fatigue of students. The author of the article adapted 4 games and tested their effectiveness during distance education of pupils of Kharkiv specialized school \#11. These studies in adapting games, which can be used in Zoom, can be continued as they make online English lessons interesting and productive. There are many other games that can be adapted during online learning.
\end{abstract}

Key words: games, online games, online English learning, distance learning, Zoom.

\section{Використання ігор під час онлайн занять 3 англійської мови на платформі Zoom (спираючись на власний досвід автора)}

\author{
Шокарьова Н. С.
}

\author{
КЗ «Харківська спеціалізована школа № 11», Харків, Україна
}

\begin{abstract}
Анотація. Стаття присвячена адаптації традиційних ігор на уроках англійської мови до використання їх під час занять на платформі для відеоконференцій Zoom, спираючись на власний досвід автора. Розвиток технологій у сучасному світі дозволяє нам виводити наші заняття за межі наших класів і проводити їх там, де ми вважаємо це зручним. Це дозволяє не зупиняти процес навчання навіть в умовах пандемії чи при якихось інших умовах, які заважають нашим учням відвідувати традиційні заняття. Використання Zоот для навчання та викладання англійської мови також надає нові можливості для перетворення звичайних завдань, до яких ми звикли під час наших занять, у незвичайні. Ігри займають важливе місце в процесі розумового розвитку учнів на різних рівнях засвоєння мови. Вони розважають, допомагають повторити та закріпити лексику, удосконалити граматичні навички, налаштуватися на урок і т. п. У той же час дистанційне навчання весною 2020 року в Україні показало необхідність використання технологій та інтернету під час навчального процесу, що в свою чергу спричинило необхідність знайти оптимальні умови, щоб не переривати навчання в умовах всесвітньої пандемії. Надмірне використання технологій веде до негативних наслідків, які позначаються на учнях. В таких умовах ігри стають не лише інструментом навчання, а й засобом досягнення максимального результату при мінімальній втомі учнів. Автором статті було адаптовано 4 гри і перевірено їх ефективність під час дистанційного навчання учнів КЗ "ХСШ №11" міста Харкова. Дані дослідження адаптації ігор, які можуть
\end{abstract}

\footnotetext{
Corresponding Author: Shokarova Nataliia Serhiivna. Tel. 098-656-85-55. E-mail: shokareff@gmail.com Kharkiv Specialised School № 11,

7 Vasylia Melnykova Street, City, Country, Ukraine, 61000.

Biдnовідальний автор: Шокарьова Наталія Сергіївна. Tel. 098-656-85-55. E-mail: shokareff@gmail.com К3 «Харківська спеціалізована школа №11», вул. Василя Мельникова, 7, Харків, Харківська область, Україна, 61000.
} 
бути використані в Zoom, можна продовжити, оскільки це робить онлайн-уроки англійської мови цікавими і продуктивними. $€$ ще багато ігор, які можна адаптувати для використання під час онлайн-навчання. Ключові слова: ігри, онлайн-ігри, онлайн-навчання англійської мови, дистанційне навчання, Zoom.

\title{
Использование игр во время онлайн-занятий по английскому языку на платформе Zoom (опираясь на собственный опыт автора)
}

\author{
Шокарева Н. С.
}

\author{
КЗ «Харьковская специализированная школа № 11», Харьков, Украина
}

\begin{abstract}
Аннотация. Статья посвящена адаптации традиционных игр на уроках английского языка к использованию их во время занятий на платформе для видеоконференций Zoom, опираясь на собственный опыт автора. Развитие технологий в современном мире позволяет нам выводить наши занятия за пределы наших классов и проводить их там, где мы считаем это удобным. Это позволяет не останавливать процесс обучения даже в условиях пандемии или при каких-то других условиях, которые мешают нашим ученикам посещать традиционные занятия. Использование Zoom для обучения и преподавания английского языка также предоставляет новые возможности для превращения обычных заданий, к которым мы привыкли во время наших занятий, в необычные. Игры занимают важное место в процессе умственного развития учеников на разных уровнях освоения языка. Они развлекают, помогают повторить и закрепить лексику, усовершенствовать грамматические навыки, настроится на урок и т.д. В то же время дистанционное обучение весной 2020 года в Украине показало необходимость использования технологий и интернета во время учебного процесса, что в свою очередь повлекло за собой необходимость найти оптимальные условия, чтобы не прерывать обучение в условиях всемирной пандемии. Чрезмерное использование технологий ведет к негативным последствиям, которые сказываются на учениках. В таких условиях игры становятся не только инструментом обучения, но и средством достижения максимального результата при минимальной усталости учащихся. Автором статьи было адаптировано 4 игры и проверено их эффеектиность во время дистанционного обучения учеников КЗ «ХСШ №11» города Харькова. Данные исследования в адаптации игр, которые могут быть использованы в Zoom, можно продолжить, поскольку это делает онлайн-уроки английского языка интересными и продуктивными. Есть еще много игр, которые можно адаптировать для использования во время онлайн-обучения.

Ключевые слова: игры, онлайн-игры, онлайн-обучение английскому языку, дистанционное обучение, Zoom.
\end{abstract}

\section{Introduction}

Games play an essential role in the process of the mental development of students on different levels of language acquisition. They entertain, motivate, stimulate and turn the process of learning into an exciting journey, although gamification can be not only interesting but also educative.

At the same time distance learning showed the necessity of using computers and the Internet as the means of teaching and studying because they became the only means of connection between a student and a teacher. Students spent too much time studying with their gadgets which increased the anxiety, nervous tension and the level of exhaustion, so the necessity of adapting some commonly used language games online arose.

"Information technologies are changing the social and communication space and create new conditions for developing heuristic dialogue. A special role is given to the Internet communication (Web-forum, audiovideo conferencing, chat, blog, e-mail, online file sharing, whiteboard, etc.), that enhance cognitivecommunicative interaction." [1]

However, not all games can be used during teaching online. That is why we would like to share our experience in using non-preparatory games online during classes in Zoom. As a result, we think that this problem is topical and needs further investigation.

The role of a teacher in conducting online classes has been changed as well. Teacher becomes a facilitator rather than an educator because under the circumstances of distance learning this is students' prerogative to choose the way and the pace of their studying, whereas educator only organizes and helps.

The aim of this article is to create the adaptations for using some common language games online to diversify your lessons in Zoom. 


\section{Materials and Methods}

Thousands of researches which investigate the importance of games for a successful learning process and development of different language skills have been created. There are works by Колесникова О.А.[2], Stronin F.M.[3], Гаврилова O.B.[4], Курбатова М. Ю.[5], Hadfield J.[6], Littlewood W.[7], Horwitz G.[8] and Monaghon D. [9]

There exist different views on games in language learning. According to M.F. Stronin game is a specially organized activity, which requires some enormous emotional and intellectual efforts. A game always involves making decisions what to do and what to say. He also considers a game as "situationally variable exercise where the possibility of multiple repetition of language patterns under conditions as close as possible to real language communication with its typical features - emotionality, spontaneity, commitment of linguistic influence is created" [3, p.47]

Several game classifications have been developed in the foreign language teaching methodology, their place and possibilities in the process of mastering various aspects of language and types of speech activity were described. We would like to discuss some of them.

M.F. Stronin's classification is one of the most quoted among experts of foreign languages. The author allocated two main types of the language games:

1. Preparatory games (grammar, lexical, phonetic, spelling) which promote the formation of speech skills.

2. Creative games (auditive and language) which are aimed at the further development of speech skills and abilities and train pupils to use them creatively. [3]

Classification of the Ukrainian researcher Yu. I. Fedusenko who is a supporter of the didactic games differentiates three types of such games [11]:

1. Didactic games that prepare for communicative activity: promote formation of language competence (phonetic, lexical, grammar, spelling).

2. Didactic games which provide communicative activity:

a) promote the formation of speech competence (in listening, speaking, reading, writing);

b) promote formation of sociocultural competence.

3. Didactic games, promoting the formation of general learning competence (the first and second groups of the mentioned didactic games).

Yu.l. Fedusenko's classification presupposes the principle of continuity in studying of foreign languages, that is gradual transition from the games aimed at the formation of language skills, to games which provide the formation and further development of the mechanisms of speaking. A mixture of learning and gaming activity is considered by the scientist as the means of formation and improvements of knowledge, skills in the process of training in foreign languages [8].

According to the psychological influence games can be divided into 2 groups:

- relaxing - remove emotional tension, caused by the load of nervous system during the studying;

- stimulating - stimulate processes of thinking, remembering, imitating the reality.

There exist a number of works which stress the importance of the usage of technology for language teaching in the classroom, among them Howland, J., Jonassen, D.H. \& Marra, R.M., Purva Chhabra [11], Kameneva N.A. and Zenina L.V. [1]. In our case computer or some gadget with similar functions became one the most important tools of studying, because without it learning literally becomes impossible during distance learning.

Games play an important role in teaching English not only in classroom, but also online. However, some adaptation needs to be done before applying some of the games during classes online.

Kameneva N.A. and Zenina L.V. suggest that "Video conferencing allows to save time and afforts. Further development of E-learning denotes a structured learning environment that integrates audio and video conferencing, text chat, interactive whiteboards, shared applications, tools of testing and feedback, forum and webinars. Thus, remote or distant learning process is performed through a combination of synchronous and asynchronous tools, while retaining the flexibility and convenience and expanding the quality and efficiency of both modes of communication." [1] All these mentioned benefits can contribute greatly to your teaching online because the program for video conferencing Zoom allows you to use whiteboard and chat functions. Besides 
your students can even share their feedback with you through the personal chat and you can share yours with them, which is very convenient and makes your classes more student-centered.

Tech experts Nik Peachey and Tom Walton present an invaluable series on using technology for teaching English in the classroom on http://www.onestopenglish.com/. "Live or pre-recorded video conferences with students can help us to give them some valuable one-to-one time that they often don't get within large (or even small) classes. This can help us to focus on individual students' needs and abilities and give us the chance to really listen to our students." [12] We totally support this idea because we can easily see each of our students, understand their reactions and make studying easier and more interesting for them.

"Video communication is more personal than any other form of web-based communication, so it can help us to create a stronger bond with our students." [12] We see our students as individuals much clearer, therefore we can help them in their learning needs.

\section{Results}

During the lockdown 2020 in Ukraine we managed to apply our theory in practice by using Zoom conferencing in teaching English for students in Kharkiv specialized school \#11. Since the change of the media of studying can influence the learning process not only beneficially, adaptation of some non-preparatory games to using online was done.

It is important to point out that games:

- promote motivation and participation (Even those students who usually do not want to take part in the classroom activities, eagerly participate in games. Those who are timid can overcome their shyness and try out something new).

- encourage cooperation and communication (Games teach students how to be sociable and interact with other people).

- develop critical thinking (Some games require solving more complicated problems and some - general critical thinking).

- develop creative abilities (We should not restrict our students to certain ideas that we think are proper ones. All ideas are accepted as long as they are grammatically correct and are used according to the rules of a game).

- lower anxiety during the lesson (Games can help create a relaxed atmosphere, thereby students can remember everything quicker and better. Games can help those students who are afraid to speak or to make a mistake. Because of their positive atmosphere mistakes become new steps in language learning).

- teach real world skills (While participating in games students learn how to work with other students, cooperate, solve problems, etc.).

- make your classes more diverse and fun for your students (Using games can give an opportunity to have fun in class even if the topic is rather complicated).

\section{Discussion}

According to M. F. Stronin's classification, the games that were used in our investigation can be classified as preparatory because some of them ("The Mime", "Categories" and "I spy...") are aimed at vocabulary acquisition and one of them ("Stretch a sentence") can be aimed at both vocabulary acquisition and grammar skills development.

We want to share 4 games that can be used as warm-up activities in Zoom, based on our experience.

"The Mime"

Who: any age/any level.

What for: practice and review vocabulary/ practice and review certain grammar structures.

How:

- Choose a student who is going to show the word and give the instructions to him/her through the chat function. Click Chat icon, then click on the participant and give your instructions to him/her. The rest of the class will not see the task. 
-The rest of the class needs to guess the word. If they know the answer, they press Raise Hand and you will see who was the first to guess the answer.

- The student who guessed the answer is the next one to show their word or sentence.

Note: this game can also be used to practise grammar such as Present Continuous, Past Simple, Present Perfect, etc. Mind that it requires more time.

\section{"Categories"}

Who: any age/any level (the number of categories can depend on the level of the participants).

What for: practice and review vocabulary of different categories; develop spelling skills.

How:

- Choose the categories. They may be diverse: from the easiest (colors, food, school objects, clothes, etc.) ones to some more complicated (jobs, countries, cities, famous places, etc.)

Our favorite ones for beginners are: food, colors, animals, clothes and places. You can be as inventive as possible for intermediate and advanced learners.

- Randomly select a letter and set the time limit of no more than 2 minutes. You can give your students one-minute time limit if they are coping fast with their tasks.

- Use Whiteboard function in Zoom and demonstrate how to build a table with categories. Later you can use it to check the words and develop spelling skills (tabl.1). This table can also be created in Word.

- If somebody gets all 5 categories filled in, they shout a funny phrase. You can invent them yourselves or choose our favourite ones: "Stop the bus!", "Dinner is ready!" or "Granny's watching!". Or participants can use Raise Hand icon to indicate that they are ready.

- Students take turns reading out their words. Students score a point for a word that no one else has.

- You can take several rounds.

Note: there might be a variation of this game for intermediate or upper intermediate learners. You can suggest a 5-letter word instead of separate letters. This makes the task more challenging but at the same time it will be more useful for your advanced students.

This task might require more than 2-minute time limit and less rounds (tabl. 2).

Tabl. 1. "Categories 1"

\begin{tabular}{|l|l|l|l|l|l|}
\hline & S & P & T & $\ldots$ & $\ldots$ \\
\hline Food & sausage & pizza & & & \\
\hline Colour & silver & purple & & & \\
\hline Animal & snake & puppy & & & \\
\hline Clothes & shorts & pyjamas & & & \\
\hline Places & shop & planet & & & \\
\hline
\end{tabular}

Tabl. 2. "Categories 2"

\begin{tabular}{|l|l|l|l|l|c|}
\hline & $\mathrm{M}$ & $\mathrm{O}$ & $\mathrm{N}$ & $\mathrm{E}$ & $\mathrm{Y}$ \\
\hline Countries & Mexico & Oman & $\ldots$ & $\ldots$ & \\
\hline Adjectives & marvellous & ordinary & $\ldots$ & $\ldots$ & \\
\hline Jobs & manager & optician & $\ldots$ & $\ldots$ & \\
\hline Hobbies & martial arts & oil painting & $\ldots$ & $\ldots$ & \\
\hline Food & meat & peanuts & $\ldots$ & $\ldots$ & \\
\hline
\end{tabular}

"I spy..."

Who: primary school students.

What for: practise and review vocabulary; develop spelling skills.

How: 
- Show a picture with a scene in the park or a picture of a teenager's bedroom or some other scene which shows lots of things and people in it. Use the Share Screen function.

- Begin the game with the words "I spy with my little eye something beginning with..."

- Class gets one minute to note down all words that they can see starting with the chosen letter.

- In a minute students take turns reading out their words. Students score a point for a word that no one else has.

- You can take several rounds.

"Stretch a sentence"

Who: any age/ any level (but more productive with intermediate students).

What for: develop writing skills; learn and practice sentence building and word order.

How:

We would like to suggest two variants for different levels of knowledge.

Here is an example of a picture that can be used with a scene in the park. (Fig. 1).

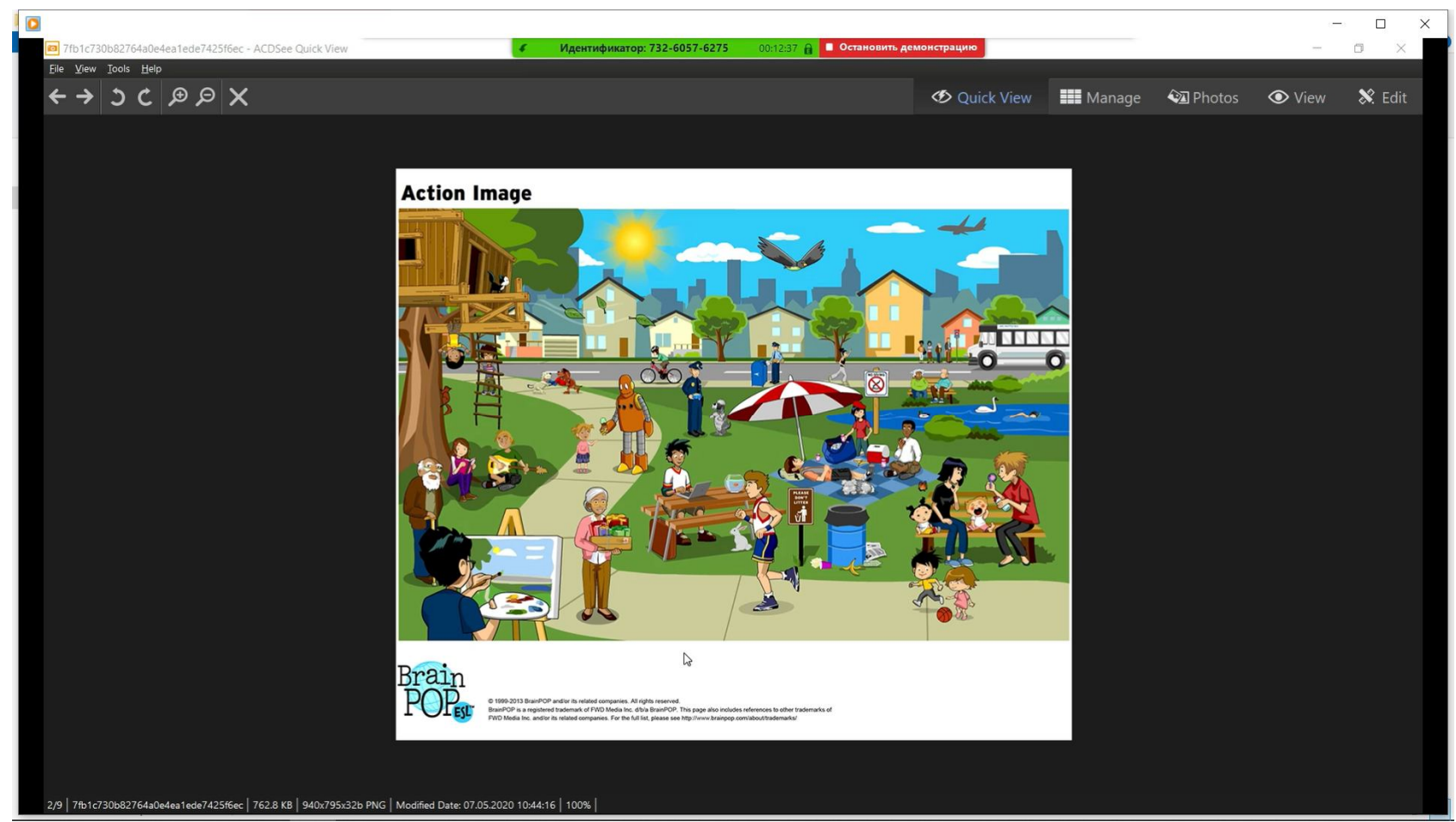

Fig. 1. Print Screen of a game in Zoom

I (Beginner level)

- Use Whiteboard function and write a short sentence using the tense that your students are familiar with.

e.g. I went for a walk.

- List the "things" they need to add using different colours:

$$
\begin{aligned}
& \text { - adjectives } \\
& \text { - when } \\
& \text { - where } \\
& \text { - why }
\end{aligned}
$$

Do this in 4 steps:

e.g. Step 1: I went for a nice walk.

Step 2: Yesterday I went for a nice walk.

Step 3: Yesterday I went for a nice walk in the park.

Step 4: Yesterday I went for a nice walk in the park because the weather was great. 
- Give students 2 minutes to "stretch" their sentences. Suggest using different colours.

- Vote for the best sentence using emoji reactions.

II (Intermediate level and higher)

- Use Whiteboard function and write 5 wh-questions to add 5 details to the sentence. Use different colours for every detail.

Step 1: who?

Step 2: what?

(Is doing what? Has done what? Will do what?)

Step 3: when?

Step 4: where?

Step 5:

- Set a 2-minute time limit.

- Check the sentences one by one or use my variation of the final point of the game: choose a different student for each step and create new sentences. Write the sentences on the Whiteboard.

- Vote for the funniest sentence with the help of emoji reactions.

"Fun gives games the magical quality that can make them irresistible to teachers trying to engage a class. Fun can transform a (mundane?) task or drill into a rewarding game. It seems logical to suggest that an activity which is fun is going to be motivating." [9] Teachers should keep this idea in mind while planning their grammar lessons because any topic can be engaging if you try turning it into a game.

We understand that our research in adapting games that can be used in Zoom should be continued as long as it makes online English classes productive and fun. There are many other games which can be adapted for using during online teaching.

\section{Conclusions}

The development of technology in modern world allows us to take our classes beyond our classrooms and conduct them wherever we find it convenient. It enables not to stop the learning process even under the pandemic conditions or under some other conditions that prevent our students from attending traditional classes. Using Zoom for learning and teaching English also provides new opportunities for making usual tasks that we are used to during our classes unusual.

To conclude, we would like to point out that our experience proved that games can be played not only in class but also during online classes. They make your Zoom classes more diverse and interesting. Playing games can provide an opportunity to relax or tune in for a class. They can help your students revise, practise and recycle vocabulary. "Stretch a sentence" can help your students develop one of the most difficult grammar skills - the word order in a sentence. Some of the games can be easily modified according to your needs and goals.

The current research has a lot of perspectives because we understand that distance learning and using modern technology is here to stay and it is no longer a theoretical question for us.

\section{Refences}

1. Kameneva, N. A., Zenina, L. V. (2013). Distance learning for developing knowledge and skills in English language teaching. Ekonomika, Statistika i Informatika, 5, 3-6.

2. Kolesnikov, O. A. (2009). Role-playing games in teaching foreign languages. Foreign languages at school, 4, 38-42. [in Russian]

3. Stronin, M. F. (2001). Training Games in English Language Lesson. Prosveshchenie, Moscow, 370. [in Russian]

4. Gavrilova, O.V. (2008). Role-playing game in teaching foreign language, 1. [in Russian]

5. Kurbatova, M. Yu. (2006). Game techniques of English grammar teaching at the initial stage. Inostrannyj yazyk v shkole, 3, 6466. [in Russian]

6. Hadfield, J. (2005). ElementaryVocabularyGames. Pearson, London, 128.

7. Littlewood, W. (1981). Communicative Language Teaching. Cambridge University Press, Cambridge, 122.

8. Horwitz, E., Young, D. (1990). Language Anxiety: From Theory \& Research To Classroom Implications. Pearson, London, 224. 
9. Monaghon, D. (2020). Playschool for grown-ups? Changing the rules of the game in language teaching. URL: http://www.onestopenglish.com/methodology/teaching-articles/teaching-approaches/playschool-for-grown-ups-changing-therules-of-the-game-in-language-teaching/154675.article (accessed 20.03.2020).

10. Fedusenko, Yu. I. (2009). Didactic game as tutorial to foreign languages of younger school students: Pedagogic science candidate thesis: 13.00.09 : Institute of pedagogics of NPS of Ukraine. Kyiv, 205. [in Ukrainian]

11. Purva, Chhabra (2012). Use of E-Learning tools in teaching English International Journal of Computing \& Business Research URL: http://www.researchmanuscripts.com/isociety2012/9.pdf (accessed 20.03.2020).

12. Educational portal. URL: http://www.onestopenglish.com/methodology/tech-tools-for-teachers/ (accessed 20.03.2020).

13. Educational portal. URL: https://www.educationworld.com/a_curr/reasons-to-play-games-in-the-classroom.shtml (accessed 20.03.2020).

14. Educational portal. URL: http://www.onestopenglish.com/teenagers/skills/games/ (accessed 20.03.2020).

15. Sklyarenko N.K. (2011). A technique of formation of foreign-language grammatical competence in pupils of general education educational institutions / N.K. Sklyarenko// Inozemni movi. - № 1. - P. 15-25. [in Ukrainian]

16. Polonskaya T. K. Game activity as means of formation key competences of recipients of primary education at lessons of a foreign language. Problemi suchasnogo pidruchnika -2018. - №21. c. 334 - 346. [in Ukrainian]

17. Grinko I.(2005). Role-playing game in study dialogical communication. English No41 (281) November 2005. P. 4-6. [in Ukrainian]

18. Kapitanchuk T.V. (2003). Role-playing game as reserve of improvement of quality and efficiency in learning foreign languages.// Anglijska mova ta literatura. - № 31. - P. 2-7. [in Ukrainian]

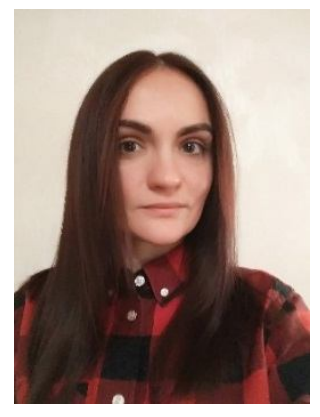

\section{Шокарьова Наталія Сергіївна.}

Вчитель вищої категорії, КЗ «Харківська спеціалізована школа №11», вул. Василя Мельникова, 7, Харків, Харківська область, Україна, 61000.

Tel. 098-656-85-55. E-mail: shokareff@gmail.com

\section{Shokarova Nataliia Serhiivna.}

Teacher, Kharkiv Specialised School № 11,

7 Vasylia Melnykova Street, City, Country, Ukraine, 61000.

Tel. 098-656-85-55. E-mail: shokareff@gmail.com

ORCID: 0000-0001-5650-9955

\section{Citation (APA):}

Shokarova, N. (2020). Using games during online English classes in Zoom (based on author's personal experience). Engineering and Educational Technologies, 8 (2), 102-109. doi: https://doi.org/10.30929/2307-9770.2020.08.02.09

\section{Цитування (ДСТУ 8302:2015):}

Шокарьова Н. С. Використання ігор під час онлайн занять з англійської мови на платформі Zoom (спираючись на власний досвід автора) / Інженерні та освітні технології. 2020. Т. 8. № 2. С. 102-109. doi: https://doi.org/10.30929/23079770.2020 .08 .02 .09

Обсяг статmі: сторінок - 8 ; умовних друк. аркушів - 1,159. 